\title{
Streptococcus bovis bacteraemia should be investigated for early detection of colorectal pathology
}

\author{
Hong Kong Med J 2019;25:414 \\ https://doi.org/10.12809/hkmj198135
}

To the Editor-We read with great interest the article titled Streptococcus gallolyticus endocarditis-an uncommon but serious complication of constipation management in the June issue of the Hong Kong Medical Journal, ${ }^{1}$ which addresses the association between endocarditis and Streptococcus gallolyticus, a subtype of the $S$ bovis group of bacteria.

We would like to share our experience in handling the same group of bacteria in the setting of the blood transfusion service. An association between $S$ bovis group bacteraemia (in particular $S$ gallolyticus subsp. gallolyticus) and colonic neoplasia is well established. ${ }^{2}$ Recently, Kwong et $\mathrm{al}^{3}$ identified $S$ gallolyticus as a colorectal cancer-related microbe.

Reviewing blood transfusion service data from 1998 to 2018, a total of 25 cases of $S$ bovis group bacteraemia were isolated in our routine bacterial surveillance programme for platelets. Although these donors were asymptomatic, in a previous study we recommended referral to public hospitals to rule out possible colonic diseases and endocarditis. ${ }^{4}$ In that study, we found that bacteraemia from $S$ gallolyticus subsp. pasteurianus could be also associated with underlying colorectal pathology. ${ }^{4}$ As a result of this connection, we routinely refer all the cases of $S$ bovis group bacteraemia for further management, irrespective of the subspecies. Among the 21 donors successfully referred, 15 donors received a colonoscopy examination. Of these 15 donors, three (20\%) were found to have colonic carcinoma, and nine $(60 \%)$ had colonic polyps (Table).

Though the case series is small, we recommend thorough examination for early detection and treatment of underlying colorectal pathology among patients with asymptomatic bacteraemia.

\section{Author contributions}

All authors had full access to the data and responsible to the follow up of the donors. SC Ng, HK Wong and CK Lee wrote the letter. All reviewed and approved the final version for publication, and take responsibility for its accuracy and integrity.

\section{Conflicts of interest}

All authors have no conflicts of interest to disclose.

SC Ng, MB, BS

HK Wong, MB, BS

CK So, MB, BS

CW Lau, FHKAM (Medicine)

Jennifer NS Leung, FHKAM (Pathology)

WC Tsoi, FHKAM (Pathology)

CK Lee *, MD, FHKAM (Medicine)

Hong Kong Red Cross Blood Transfusion Service, Hong Kong

*Corresponding author: ckleea@ha.org.hk

\section{References}

1. Leung JS. Streptococcus gallolyticus endocarditis-an uncommon but serious complication of constipation management. Hong Kong Med J 2019;25:257.

TABLE. Outcome of the 25 cases of Streptococcus bovis* bacteraemia in blood donors

\begin{tabular}{lcccc}
\hline & S bovis & $\begin{array}{c}\text { S gallolyticus } \\
\text { subsp. } \\
\text { gallolyticus }\end{array}$ & $\begin{array}{c}\text { S. gallolyticus } \\
\text { subsp. } \\
\text { pasteurianus }\end{array}$ & $\begin{array}{c}\text { Total } \\
(\mathbf{n}=25)\end{array}$ \\
\hline Colorectal carcinoma & 2 & 0 & 1 & 3 \\
\hline Colorectal adenoma & 6 & 1 & 2 & 9 \\
Normal colonoscopy & 2 & 0 & 1 & 3 \\
No colonoscopy performed & 4 & 0 & 2 & 6 \\
Not able to contact & 3 & 0 & 1 & 4 \\
\hline
\end{tabular}

* Where the isolate was not available for $16 \mathrm{~S}$ rDNA sequencing, it was designated as "Streptococcus bovis"
2. Boleij A, van Gelder MM, Swinkels DW, Tjalsma H. Clinical importance of Streptococcus gallolyticus infection among colorectal cancer patients: systematic review and meta-analysis. Clin Infect Dis 2011;53:870-8.

3. Kwong TN, Wang X, Nakatsu G, et al. Association between bacteremia from specific microbes and subsequent diagnosis of colorectal cancer. Gastroenterology 2018;155:383-90.

4. Lee CK, Chan HM, Ho PL, et al. Long-term clinical outcomes after Streptococcus bovis isolation in asymptomatic blood donors in Hong Kong. Transfusion 2013;53:2207-10. 